\title{
Pharmacogenetics may explain part of the interindividual variability of dobutamine pharmacodynamics in neonates
}

\author{
Maarja Hallik ${ }^{1}$, Hiie Soeorg${ }^{1}$, Tiina Kahre ${ }^{2}$, Ülle Murumets $^{2}$, Mari-Liis Ilmoja ${ }^{3}$, Karin \\ Kipper $^{4}$, and Tuuli Metsvaht ${ }^{1}$ \\ ${ }^{1}$ University of Tartu \\ ${ }^{2}$ Tartu University Hospital \\ ${ }^{3}$ Tallinn Children's Hospital \\ ${ }^{4}$ Chalfont Centre for Epilepsy
}

January 26, 2022

\begin{abstract}
Aim: To determine whether the known single nucleotide polymorphisms in adrenoreceptor associated genes affect the hemodynamic response to dobutamine in critically ill neonates. Methods: Alleles in the known genetic single nucleotide polymorphisms in $\beta 1$ and $\beta 2$ adrenoceptor (AR) genes and Gs protein $\alpha$-subunit gene (GNAS) possibly affecting inotropic effect were identified in patients of neonatal dobutamine pharmacokinetic-pharmacodynamic study. Linear mixed-effect models were used to describe the effect of genetic polymorphisms to heart rate (HR), left ventricular output (LVO) and right ventricular output (RVO) during dobutamine treatment. Results: 26 neonates ( 5 term, 21 preterm) were studied. Dobutamine plasma concentration and exposure time respective HR (adjusted to gestational age) is dependent on $\beta 1-\mathrm{AR}$ Arg389Gly polymorphism so that in G/G (Gly) homozygotes and G/C heterozygotes dobutamine increases HR more than in C/C (Arg) homozygotes, with parameter estimate $(95 \% \mathrm{CI})$ of $38.3(15.8-60.7) \mathrm{bpm}$ per AUC of $100 \mathrm{mg} \cdot \mathrm{h}, \mathrm{p}=0.0005$. LVO (adjusted to antenatal glucocorticoid administration and illness severity) and RVO (adjusted to gestational age and illness severity) is dependent on GNAS c.393C $>$ T polymorphism so that in $\mathrm{T} / \mathrm{T}$ homozygotes and $\mathrm{C} / \mathrm{T}$ heterozygotes but not in $\mathrm{C} / \mathrm{C}$ homozygotes $\mathrm{LVO}$ and RVO increase with dobutamine treatment, $24.5(6.2-42.9) \mathrm{mL} \mathrm{kg-1} \mathrm{min}-1$ per AUC of $100 \mathrm{mg} \cdot \mathrm{h}, \mathrm{p}=0.0116$ and $33.2(12.1-54.3) \mathrm{mL} \mathrm{kg}-1 \mathrm{~min}-1 \mathrm{per}$ AUC of $100 \mathrm{mg} \cdot \mathrm{h}, \mathrm{p}=0.0025$, respectively. Conclusion: In critically ill neonates, $\beta 1$-AR Arg389Gly and GNAS c.393C $>$ T polymorphisms may play a role in the haemodynamic response to dobutamine during the first hours and days of life.
\end{abstract}

Pharmacogenetics may explain part of the interindividual variability of dobutamine pharmacodynamics in neonates

Maarja Hallik ${ }^{1}$, Hiie Soeorg ${ }^{2}$, Tiina Kahre ${ }^{3,4}$, Ülle Murumets ${ }^{3}$, Mari-Liis Ilmoja ${ }^{5}$, Karin Kipper ${ }^{6,7,8}$, Tuuli Metsvaht ${ }^{9}$

The authors confirm that the PI for this paper is Maarja Hallik and that she had direct clinical responsibility for patients.

${ }^{1}$ Department of Anaesthesiology and Intensive Care, Institute of Clinical Medicine, University of Tartu, Tartu, Estonia

${ }^{2}$ Department of Microbiology, Institute of Biomedicine and Translational Medicine, University of Tartu, Tartu, Estonia

${ }^{3}$ Department of Clinical Genetics, United Laboratories, Tartu University Hospital, Tartu, Estonia

${ }^{4}$ Department of Clinical Genetics, Institute of Clinical Medicine, University of Tartu, Tartu, Estonia 
${ }^{5}$ Department of Anaesthesiology and Intensive Care, Tallinn Children's Hospital, Tallinn, Estonia

${ }^{6}$ Institute of Chemistry, University of Tartu, Tartu, Estonia

${ }^{7}$ Chalfont Centre for Epilepsy, Buckinghamshire, United Kingdom

${ }^{8}$ Department of Clinical and Experimental Epilepsy, Faculty of Brain Sciences, University College London, United Kingdom

${ }^{9}$ Department of Paediatrics, Institute of Clinical Medicine, University of Tartu, Tartu, Estonia

Running head: Dobutamine pharmacogenetics in neonates

Keywords: neonatology, intensive care, cardiovascular pharmacology, pharmacogenetics.

Corresponding author: Maarja Hallik, Department of Anaesthesiology and Intensive Care, Institute of Clinical Medicine, University of Tartu, L. Puusepa 8 - G1. 209, 50406, Tartu, Estonia; e-mail: maarja.hallik@ut.ee ; phone: 003725055369;

Word count: 3804 , table count: 2 , figure count: 3

What is already known about this subject?

Some genetic variation in human cardiac $\beta$-adrenoceptor pathway that might result in different response to inotropic therapy have been described.

In vivo data about the effects of genetic variation to cardiovascular response come from adult studies with small number of healthy volunteers or heart failure patients.

What this study adds?

- The study describes the genetic variability in dobutamine pharmacodynamics in critically ill neonates.

- The large interindividual variability of the cardiovascular effects of dobutamine in early postnatal life may partly be explained by adrenoceptor and Gs protein $\alpha$-subunit gene sequence variants.

- Results from adult studies cannot be readily extrapolated to neonates.

\section{ABSTRACT}

Aim: To determine whether the known single nucleotide polymorphisms in adrenoreceptor associated genes affect the hemodynamic response to dobutamine in critically ill neonates.

Methods: Alleles in the known genetic single nucleotide polymorphisms in $\beta 1$ and $\beta 2$ adrenoceptor (AR) genes and Gs protein $\alpha$-subunit gene (GNAS) possibly affecting inotropic effect were identified in patients of neonatal dobutamine pharmacokinetic-pharmacodynamic study. Linear mixed-effect models were used to describe the effect of genetic polymorphisms to heart rate (HR), left ventricular output (LVO) and right ventricular output (RVO) during dobutamine treatment.

Results: 26 neonates ( 5 term, 21 preterm) were studied. Dobutamine plasma concentration and exposure time respective HR (adjusted to gestational age) is dependent on $\beta 1$-AR Arg389Gly polymorphism so that in G/G (Gly) homozygotes and G/C heterozygotes dobutamine increases HR more than in C/C (Arg) homozygotes, with parameter estimate $(95 \% \mathrm{CI}$ ) of $38.3(15.8-60.7) \mathrm{bpm}$ per AUC of $100 \mathrm{mg} \cdot \mathrm{h}, \mathrm{p}=0.0005$. LVO (adjusted to antenatal glucocorticoid administration and illness severity) and RVO (adjusted to gestational age and illness severity) is dependent on GNAS c.393C $>\mathrm{T}$ polymorphism so that in $\mathrm{T} / \mathrm{T}$ homozygotes and $\mathrm{C} / \mathrm{T}$ heterozygotes but not in $\mathrm{C} / \mathrm{C}$ homozygotes LVO and RVO increase with dobutamine treatment, 24.5 $(6.2-42.9) \mathrm{mL} \mathrm{kg}{ }^{-1} \mathrm{~min}^{-1}$ per AUC of $100 \mathrm{mg} \cdot \mathrm{h}, \mathrm{p}=0.0116$ and $33.2(12.1-54.3) \mathrm{mL} \mathrm{kg}^{-1} \mathrm{~min}^{-1}$ per AUC of $100 \mathrm{mg} \cdot \mathrm{h}, \mathrm{p}=0.0025$, respectively.

Conclusion: In critically ill neonates, $\beta 1$-AR Arg389Gly and GNAS c.393C $>$ T polymorphisms may play a role in the haemodynamic response to dobutamine during the first hours and days of life. 


\section{INTRODUCTION}

Some variability in drug response can be explained by genetic variability in drug targets. Single nucleotide polymorphisms (SNP) in receptor encoding genes, may result in altered function, substrate binding affinity, expression, and both up- and downregulation of receptors. ${ }^{1}$

In the cardiac $\beta$-adrenoceptor (AR) pathway $\beta$-ARs themselves and Gs protein $\alpha$-subunit

have been found to date to display some genetic variation in humans that might result in different response to inotropic therapy. ${ }^{2}$

The $\beta 1$-AR gene (ADRB1 ; RefSeq NM_000684.2) has two commonly variable sites, at amino acid positions 49 and 389. The most studied AR gene polymorphism is the Arg389Gly human $\beta 1$-AR gene polymorphism. It is associated with significantly elevated adenylate cyclase (AC)/protein kinase A activities and hence $\beta 1$-AR- stimulated cardiac contractility in the Arg389 variant carriers compared with Gly389 carriers. $^{3}$

Arg389 $\beta 1$-AR is more common than Gly389 $\beta 1 \mathrm{AR}$ in individuals of European descent.

A second human $\beta 1$-AR polymorphism is the p.Ser49Gly variation, associated with increased long-term agonist-promoted receptor downregulation for the Gly49 over the Ser49 variant. ${ }^{4,5}$ The beneficial effect of Gly49 variant on survival of heart-failure patients, is supporting the concept that $\beta 1$-AR desensitization is protective in heart failure. ${ }^{6}$

Three nonsynonymous polymorphisms have been shown to exist in the coding region of the $\beta 2$-AR gene (ADRB2, RefSeq NM_000024.5), at amino acid positions 16, 27, and 164. ${ }^{7}$ Gly16Arg and Gln27Glu variations are in linkage disequilibrium and thus constitute a haplotype, which affects receptor downregulation. And a third polymorphism, Thr164Ile, a rare polymorphism (Ile164, heterozygous frequency $\sim 0.03$ ) that confers impaired receptor $\mathrm{G}$ protein coupling and reduced acetylcholine mediated signalling, resulting in severely depressed or absent agonist-promoted cardiac contractility. ${ }^{8-10}$

The $\beta$-AR-Gs protein system is essential for the activation of AC in cardiac smooth muscle, which regulates cardiac output and peripheral vascular resistance. ${ }^{11,12}$ Retrospective studies suggest that the c.393C $>\mathrm{T}$ polymorphism in the human gene encoding the $\alpha$-subunit of Gs protein (GNAS, RefSeq NM_000516.4) has an effect on response to $\beta$-blockade and heart rate after exercise stress test. ${ }^{13,14}$ Data from a prospective study suggest that the c.393C $>$ T polymorphism of GNAS is functionally relevant in vivo . The results of a modified dobutamine stress echocardiography protocol show that individuals with homozygous or heterozygous C393 have an increased cardiovascular agonistic response to dobutamine. ${ }^{15}$

According to PharmGKB database, $\beta 1$-AR gene Arg389Gly and GNAS gene c.393C $>$ T polymorphisms are associated with haemodynamic response to dobutamine in vivo . ${ }^{16}$ However, there are no data on the effect of the genetic variability of $\beta$-ARs or Gs protein $\alpha$-subunit on haemodynamic response to agonist stimulation in early neonatal life.

Our study aimed to find out whether the known SNPs in the $\beta 1-, \beta 2-A R$ and GNAS genes play a role in the variability of cardiovascular response to dobutamine treatment in critically ill neonates.

\section{METHODS}

The study was conducted as a sub study of dobutamine pharmacokinetic-pharmacodynamic (PKPD) study, approved by the Ethics Committee of the University of Tartu and registered at the EU Clinical Trials Register under number 2015-004836-36. A prospective 2-centre study was performed from April 2016 to December 2017 in Tallinn Children's Hospital, Tallinn, Estonia and Tartu University Hospital, Tartu, Estonia. Full details of the study can be found elsewhere. ${ }^{17}$

Briefly, neonates hospitalised to NICU within the first 72 hours of life and needing inotropic therapy were studied. Written informed consent for genetic analysis was signed by parents or guardians separately from the main dobutamine PKPD study consent before study inclusion. 
Whole blood samples of $0.3 \mathrm{ml}$ were collected from indwelling arterial or venous catheter within the study period. The samples were transported immediately to the Department of Clinical Genetics, United Laboratories, Tartu University Hospital, Tartu, Estonia. DNA was extracted from blood lymphocytes by Nucleospin Tissue kit (Macherey-Nagel). Sanger sequencing was performed for ADRB1 gene exon 1, ADRB2 gene exon 1 and GNAS gene exon 5, accordingly including the following variants of interest: $\beta 1$-AR p.Gly389Arg, $\beta 1$-AR p.Ser49Gly, $\beta 2$-AR Gly16Arg, $\beta 2$-AR Gln27Glu, GNAS c.393C $>$ T. PCR primers used are provided in Supplementary Table 1. Sanger sequencing was performed with same primers as for PCR amplification and products were sequenced bidirectionally using ABI GeneScan 3130XL instrument.

Dobutamine was administered at escalating doses of 5-20 $\mu \mathrm{g} \mathrm{kg}^{-1} \mathrm{~min}^{-1}$. Monitoring and recording of heart rate (HR) and mean arterial pressure (MAP) were started before dobutamine infusion and continued throughout the treatment period, left ventricular ejection fraction (LVEF), left and right ventricular cardiac output (LVO, RVO) were measured before and repeatedly during the dobutamine treatment. ${ }^{17}$

The effect of SNPs on haemodynamic parameters (HR, MAP, LVEF, LVO and RVO) was analysed with linear mixed-effects models separately for each SNP. The model building process was started with full model including gestational age (GA), Score for Neonatal Acute Physiology Perinatal Extension (SNAPPE-II) ${ }^{18}$, age at recruitment, antenatal glucocorticoid administration (only if GA $<34$ weeks), exposure to dobutamine measured as the area under the time-plasma concentration curve (AUC) calculated according to the published dobutamine population pharmacokinetic model using empirical Bayes estimates of pharmacokinetic parameters in each neonate, and interaction between AUC and SNP as fixed effects and random intercept and random slope of AUC for each neonate. ${ }^{17}$ Stepwise backward elimination was used to retain only statistically significant effects into model. Autocorrelation structure of order 1 with time after dose (in minutes) as covariate was used in models for HR and MAP.

Key protein targets and ligands in this article are hyperlinked to corresponding entries in http://www.guidetopharmacology.org, the common portal for data from the IUPHAR/BPS Guide to PHARMACOLOGY.

\section{RESULTS}

Overall, 26 of the 28 PKPD study participants were consented to the pharmacogenomic study. The median (range) gestational age was $30.9(22.7-41.0)$ weeks, birth weight $1668(465-4380) \mathrm{g}$, age at recruitment $6.3(2.4-27.5) \mathrm{h}$, SNAPPE-II scores $14.5(3.0$ - 64.0), 5 min APGAR score $7(1-8)$, baseline LVEF 62.5 $\left(51.0\right.$ - 79.0) \%, RVO $126(75-306) \mathrm{mL} \mathrm{kg}^{-1} \mathrm{~min}^{-1}$, LVO $128(71-232) \mathrm{mL} \mathrm{kg}^{-1} \mathrm{~min}^{-1}$.

The incidences of investigated alleles were comparable to those of general population

of Estonia in all observed SNPs. (Table 1)

We found that $\beta 1$-AR Arg389Gly polymorphism influences HR increase during dobutamine treatment and GNAS c.393C > T polymorphism affects cardiac output response to dobutamine. The other studied SNPs did not show statistically significant effect on dobutamine induced changes in HR, MAP, cardiac output or LVEF. The linear mixed-effect models, where the effect of SNPs on hemodynamic parameters was statistically significant are presented in Table 2. HR adjusted to GA is dependent on $\beta 1$ - AR Arg389Gly polymorphism so that in G/G (Gly) homozygotes and G/C heterozygotes dobutamine increases HR more steeply than in $\mathrm{C} / \mathrm{C}(\mathrm{Arg})$ homozygotes $(\mathrm{p}=0.0008)$. (Figure 1) LVO adjusted to antenatal glucocorticoid administration and SNAPPE-II is dependent on GNAS c.393C $>\mathrm{T}$ polymorphism so that in $\mathrm{T} / \mathrm{T}$ homozygotes and $\mathrm{C} / \mathrm{T}$ heterozygotes but not in $\mathrm{C} / \mathrm{C}$ homozygotes $\mathrm{LVO}$ increases during dobutamine treatment $(\mathrm{p}=0.0095)$. (Figure 2) RVO adjusted to SNAPPE-II and GA is dependent on GNAS c.393C $>$ T polymorphism so that in T/T homozygotes and $\mathrm{C} / \mathrm{T}$ heterozygotes but not in $\mathrm{C} / \mathrm{C}$ homozygotes $\mathrm{RVO}$ increases with dobutamine treatment $(\mathrm{p}=0.0025)$. (Figure 3)

Individual measured haemodynamic parameter values, population (marginal) and individual (conditional) predictions from the final linear mixed effects models plotted against dobutamine AUC are presented in the supplementary figures S1-S3. 


\section{DISCUSSION}

To the best of our knowledge this is the first study demonstrating the role of polymorphisms in the $\beta$-AR pathway related genes in the variability of response to inotropic therapy in critically ill neonates. The main findings of the study were associations between Arg389Gly polymorphism in $\beta 1$-AR gene and HR as well as GNAS c.393C $>$ T polymorphism and cardiac output (RVO and LVO).

There is only sparse clinical data about the influence of studied variants and cardiovascular response to inotropes. In our study, $\beta 1$-AR Arg389 homozygotes had lower heart rate in response to dobutamine compared to heterozygotes and Gly389 homozygotes, with no effect on RVO or LVO. In contrast, previous studies in adults found that human hearts with Arg389 $\beta 1$-AR variant, from both healthy subjects and patients with heart failure, had substantially greater agonist-induced inotropy compared with hearts from Gly389 carriers, in an ex vivoexperiment. ${ }^{20}$ Healthy male volunteers homozygous for the Arg389 $\beta 1$-AR showed significantly higher increase in fractional shortening upon cumulative doses of dobutamine as compared to subjects carrying one or two copies of the Gly389 allele. ${ }^{21}$ In a study of 10 and 8 male subjects homozygous Arg389 $\beta 1-A R$ and Gly389 $\beta 1-A R$, respectively (to avoid influences of codon 49 polymorphism, all were homozygous Ser49 $\beta 1-A R$ ), dobutamine increased plasma-renin activity, heart rate and contractility and decreased diastolic blood pressure more potently in Arg389 $\beta 1$-AR versus Gly389 $\beta 1$-AR subjects. ${ }^{22}$. In healthy individuals, HR and renin responses to dobutamine in incremental doses were more than three-fold greater among $\beta 1$-AR Arg389 compared with Gly389 homozygotes. ${ }^{23}$ In the same study population, no significant difference was found in haemodynamic response to dobutamine constant infusion between $\beta 1$-AR 389 genotypes. ${ }^{24}$ The difference in the effect on chronotropy in neonates, compared to adults, may be explained by developmental physiology as well as differences in $\beta$-AR signalling in the immature heart. As in neonates, especially in the premature and critically ill with cardiac failure, HR is already high before treatment, the lower HR in response to dobutamine treatment in Arg389 $\beta 1$-AR subjects may refer to better response to inotropic treatment, with sequence variant specific difference in the change in contractility not captured by our measurement methods.

We also found the effect of GNAS c.393C > T polymorphism on cardiac output during dobutamine treatment, $\mathrm{T}$ allele carriers increasing RVO and LVO in response to dobutamine compared to no change or decrease in C/C homozygotes. (Figures S2, S3) The only in vivo prospective study in 18 healthy Chinese adults showed that individuals with homozygous or heterozygous C393 had an increased cardiovascular agonistic response to dobutamine. ${ }^{15}$ This controversy remains difficult to explain, as the exact molecular mechanism of the effect of the GNAS c.393C > T polymorphism has not been identified ${ }^{25}$ Further studies are urgently needed, as our very first data in the field suggest potential untoward effect of decreasing LVO and RVO with increasing dobutamine exposure in $\mathrm{C} / \mathrm{C}$ homozygous neonates.

Three of the studied polymorphisms ( $\beta 1$-AR Ser49Gly and $\beta 2$-AR Gly16Arg and Gln27Glu) have been associated with agonist promoted receptor desensitisation and downregulation. ${ }^{4,5,8-10}$ The lack of association between these SNPs and cardiovascular response to dobutamine in our study population may be explained by ontogeny of $\beta$-ARs. Results of juvenile animal studies indicate that $\beta$-ARs in the neonatal heart do not desensitize in response to agonist stimulation. ${ }^{26-29}$ Furthermore, the maintenance of cardiac $\beta$-AR signalling in the face of intense stimulation is likely to play an important role in the physiologic adaptation during perinatal transition. ${ }^{30}$ One study on preterm foetal sheep demonstrates the downregulation of $\beta$-AR with prolonged dobutamine treatment in preterm heart exposed to hypoxia-ischemia. ${ }^{31}$ The lack of the clinical evidence of receptor downregulation in our study may have been influenced by the relatively short observational period.

In addition to the unique situation of transitional circulatory response in neonates several perinatal factors/ interventions, like prematurity, glucocorticoid exposure or hypoxia-ischemia may contribute to the effects of sequence variants on dobutamine response. ${ }^{31,32}$ Hence GA, age at recruitment, antenatal glucocorticoid administration status and SNAPPE-II score as a marker for perinatal illness severity were chosen to be included to the multivariable linear models describing the effect of genetic variability to the haemodynamic response to dobutamine. 
Developmental changes in the expression of $\mathrm{G}$ protein subunits may account for different response to $\beta$ adrenergic stimulation in adult and neonatal populations. ${ }^{33}$

Enhanced role of $\beta 2-\mathrm{AR}$ and $\beta 3$-AR, as compared to $\beta 1$-AR, in chronotropic effects of $\beta$-adrenergic agonists has been suggested in both immature rat and large mammal heart. Possible underlying mechanism include immature coupling between $\beta 1$-AR and Gs in the early postnatal period. ${ }^{34}$

In our relatively small study group, we could not detect the role of the studied genetic polymorphisms in predisposition to haemodynamic instability and need for inotropic treatment during the transitional period. The allele incidences of all studied SNPs were comparable to the general population. It has been shown that in term neonates $\beta 1$-AR Gly49 homozygosity may predispose to transient tachypnoea of the neonate. ${ }^{35}$ The possible role of AR related genetic variations in perinatal cardiac failure needs to be addressed in larger association studies.

The low number of participants is a major limitation of our study. Assessment of cardiac function by ultrasound is operator dependent with large inter-occasion and -observer variability. To limit this effect all cardiac ultrasound studies were performed by 5 cardiologists in our study and in each patient all examinations were performed by the same specialist throughout the study period. Relatively short haemodynamic data collection period limited the assessment of time-consuming processes like receptor downregulation.

Conclusions. Our results suggest, that the large interindividual variability of the cardiovascular effects of dobutamine in early postnatal life may partly be explained by AR and GNAS sequence variants. Larger pharmacogenomic studies are urgently needed for better targeted dobutamine therapy in neonates. Results from adult studies cannot be readily extrapolated to younger age groups due to developmental differences in beta-adrenergic signalling and the physiology of early transitional circulation.

\section{ACKNOWLEDGEMENTS}

The study was funded by the Estonian Research Council (PUT1197). MH received support from the University of Tartu Foundation (Professor Lembit Allikmets' and Heino Kruse's foundations).

The authors have no conflicts of interest to declare.

\section{REFERENCES}

1. Evans WE, McLeod HL. Pharmacogenomics - Drug Disposition, Drug Targets, and Side Effects. Wood AJJ, ed. N Engl J Med . 2003;348(6):538-549. doi:10.1056/NEJMra020526

2. Lymperopoulos A, Garcia D, Walklett K. Pharmacogenetics of cardiac inotropy. Pharmacogenomics . 2014;15(14):1807-1821. doi:10.2217/pgs.14.120

3. Sandilands AJ, O'Shaughnessy KM, Brown MJ. Greater inotropic and cyclic AMP responses evoked by noradrenaline through Arg389 beta 1-adrenoceptors versus Gly389 beta 1-adrenoceptors in isolated human atrial myocardium. Br J Pharmacol . 2003;138(2):386-392. doi:10.1038/sj.bjp.0705030

4. Rathz DA, Brown KM, Kramer LA, Liggett SB. Amino acid 49 polymorphisms of the human beta1adrenergic receptor affect agonist-promoted trafficking. J Cardiovasc Pharmacol . 2002;39(2):155-160. doi:10.1097/00005344-200202000-00001

5. Levin MC, Marullo S, Muntaner O, Andersson B, Magnusson Y. The myocardium-protective Gly-49 variant of the beta 1-adrenergic receptor exhibits constitutive activity and increased desensitization and down-regulation. J Biol Chem . 2002;277(34):30429-30435. doi:10.1074/jbc.M200681200

6. Börjesson M, Magnusson Y, Hjalmarson A, Andersson B. A novel polymorphism in the gene coding for the beta(1)-adrenergic receptor associated with survival in patients with heart failure. Eur Heart $J$. 2000;21(22):1853-1858. doi:10.1053/euhj.1999.1994

7. Small KM, McGraw DW, Liggett SB. Pharmacology and physiology of human adrenergic receptor polymorphisms. Annu Rev Pharmacol Toxicol . 2003;43:381-411. doi:10.1146/annurev.pharmtox.43.100901.135823 
8. Johnson JA, Liggett SB. Cardiovascular pharmacogenomics of adrenergic receptor signaling: clinical implications and future directions. Clin Pharmacol Ther . 2011;89(3):366-378. doi:10.1038/clpt.2010.315

9. Dorn GW. Adrenergic Signaling Polymorphisms and Their Impact on Cardiovascular Disease. Physiol Rev . 2010;90(3):1013-1062. doi:10.1152/physrev.00001.2010

10. Green SA, Turki J, Innis M, Liggett SB. Amino-terminal polymorphisms of the human beta 2-adrenergic receptor impart distinct agonist-promoted regulatory properties. Biochemistry . 1994;33(32):9414-9419. doi:10.1021/bi00198a006

11. Eschenhagen T. G proteins and the heart. Cell Biol Int . 1993;17(8):723-750. doi:10.1006/cbir.1993.1135

12. Asano M, Masuzawa K, Matsuda T, Asano T. Reduced function of the stimulatory GTP-binding protein in beta adrenoceptor-adenylate cyclase system of femoral arteries isolated from spontaneously hypertensive rats. J Pharmacol Exp Ther . 1988;246(2).

13. Jia $H$, Hingorani AD, Sharma $P$, et al. Association of the $G_{\mathrm{s}} \alpha$ Gene With Essential Hypertension and Response to $\beta$-Blockade. Hypertension . 1999;34(1):8-14. doi:10.1161/01.HYP.34.1.8

14. Nieminen T, Lehtimäki T, Laiho J, et al. Effects of polymorphisms in $\beta_{1}$-adrenoceptor and $\alpha$-subunit of $\mathrm{G}$ protein on heart rate and blood pressure during exercise test. The Finnish Cardiovascular Study. $J$ Appl Physiol . 2006;100(2):507-511. doi:10.1152/japplphysiol.00899.2005

15. Mao Y-M, Liu Z-Q, Chen B-L, et al. Effect of 393T\&gt;C polymorphism of GNAS1 gene on dobutamine response in Chinese healthy subjects.J Clin Pharmacol . 2009;49(8):929-936. doi:10.1177/0091270009337945

16. Whirl-Carrillo M, McDonagh EM, Hebert JM, et al. Pharmacogenomics knowledge for personalized medicine. Clin Pharmacol Ther . 2012;92(4):414-417. doi:10.1038/clpt.2012.96

17. Hallik M, Ilmoja M, Standing JF, et al. Population pharmacokinetics and pharmacodynamics of dobutamine in neonates on the first days of life. Br J Clin Pharmacol . 2020;86(2):318-328. doi:10.1111/bcp.14146

18. Richardson DK, Corcoran JD, Escobar GJ, Lee SK. SNAP-II and SNAPPE-II: Simplified newborn illness severity and mortality risk scores. J Pediatr . 2001;138(1):92-100. doi:10.1067/mpd.2001.109608

19. Karczewski KJ, Francioli LC, Tiao G, et al. The mutational constraint spectrum quantified from variation in 141,456 humans.Nature . 2020;581(7809):434-443. doi:10.1038/s41586-020-2308-7

20. Liggett SB, Mialet-Perez J, Thaneemit-Chen S, et al. A polymorphism within a conserved beta(1)adrenergic receptor motif alters cardiac function and beta-blocker response in human heart failure. Proc Natl Acad Sci U S A . 2006;103(30):11288-11293. doi:10.1073/pnas.0509937103

21. La Rosée K, Huntgeburth M, Rosenkranz S, Böhm M, Schnabel P. The Arg389Gly beta1-adrenoceptor gene polymorphism determines contractile response to catecholamines. Pharmacogenetics . 2004;14(11):711716. doi:10.1097/00008571-200411000-00001

22. Bruck H, Leineweber $\mathrm{K}$, Temme $\mathrm{T}$, et al. The Arg389Gly beta1-adrenoceptor polymorphism and catecholamine effects on plasma-renin activity. $J$ Am Coll Cardiol . 2005;46(11):2111-2115. doi:10.1016/j.jacc.2005.08.041

23. Yogev D, Basheer M, Blotnick S, Caraco Y, Muszkat M. Effects of sex and the common ADRB1 389 genetic polymorphism on the hemodynamic response to dobutamine. Pharmacogenet Genomics . 2015;25(11):555563. doi:10.1097/FPC.0000000000000174

24. Yogev D, Basheer M, Perlman A, Blotnick S, Caraco Y, Muszkat M. The hemodynamic response to constant dobutamine infusion.Pharmacogenet Genomics . 2018;28(6):139-146. doi:10.1097/FPC.0000000000000338

25. Klenke S, Siffert W. SNPs in genes encoding G proteins in pharmacogenetics. Pharmacogenomics . 2011;12(5):633-654. doi:10.2217/pgs.10.203 
26. Stein HM, Oyama K, Sapien R, Chappell BA, Padbury JF. Prolonged beta-agonist infusion does not induce desensitization or down-regulation of beta-adrenergic receptors in newborn sheep. Pediatr Res . 1992;31(5):462-467. doi:10.1203/00006450-199205000-00009

27. Giannuzzi CE, Seidler FJ, Slotkin TA. $\beta$-adrenoceptor control of cardiac adenylyl cyclase during development: agonist pretreatment in the neonate uniquely causes heterologous sensitization, not desensitization.Brain Res . 1995;694(1-2):271-278. doi:10.1016/0006-8993(95)00781-K

28. Zeiders JL, Seidler FJ, Slotkin TA. Ontogeny of Regulatory Mechanisms for $\beta$-Adrenoceptor Control of Rat Cardiac Adenylyl Cyclase: Targeting of G-Proteins and the Cyclase Catalytic Subunit. J Mol Cell Cardiol . 1997;29(2):603-615. doi:10.1006/JMCC.1996.0303

29. Zeiders JL, Seidler FJ, Iaccarino G, Koch WJ, Slotkin TA. Ontogeny of Cardiacß-Adrenoceptor Desensitization Mechanisms: Agonist Treatment Enhances Receptor/G-Protein Transduction Rather than Eliciting Uncoupling. J Mol Cell Cardiol . 1999;31(2):413-423. doi:10.1006/JMCC.1998.0875

30. Zeiders J., Seidler F., Slotkin T. Ontogeny of G-protein expression: control by $\beta$-adrenoceptors. Dev Brain Res . 2000;120(2):125-134. doi:10.1016/S0165-3806(99)00188-1

31. Hutchinson DS, Brew N, Vu T, et al. Effects of hypoxia-ischemia and inotropes on expression of cardiac adrenoceptors in the preterm fetal sheep. $J$ Appl Physiol . 2018;125(5):1368-1377. doi:10.1152/japplphysiol.00472.2018

32. Kim MY, Finch AM, Lumbers ER, et al. Expression of adrenoceptor subtypes in preterm piglet heart is different to term heart. PLoS One . 2014;9(3):e92167. doi:10.1371/journal.pone.0092167

33. Fattal O, Van Dop C, Chen F, et al. Steady-state mRNA levels of G protein subunits in developing rabbit myocardium. Biochem Mol Med . 1995;56(2):108-114. doi:10.1006/bmme.1995.1065

34. Oliveira ES, Pereira AH, Cardoso AC, Franchini KG, Bassani JWM, Bassani RA. Atrial chronotropic reactivity to catecholamines in neonatal rats: Contribution of $\beta$-adrenoceptor subtypes. Eur J Pharmacol . 2015;764:385-394. doi:10.1016/j.ejphar.2015.07.031

35. Aslan E, Tutdibi E, Martens S, Han Y, Monz D, Gortner L. Transient tachypnea of the newborn (TTN): A role for polymorphisms in the $\beta$-adrenergic receptor (ADRB) encoding genes? Acta Paediatr . 2008;97(10):1346-1350. doi:10.1111/j.1651-2227.2008.00888.x

Table 1. The incidence of studied SNP alleles in the study population and Estonian population.

\begin{tabular}{|c|c|c|c|c|c|}
\hline Patient ID & $\begin{array}{l}\beta 2-A R \quad 46 A>G \\
\text { Gly16Arg }\end{array}$ & $\begin{array}{l}\beta 2-\mathrm{AR} 79 \mathrm{C}>\mathrm{G} \\
\text { Gln27Glu }\end{array}$ & $\begin{array}{l}\beta 1-\mathrm{AR} \\
\text { c.1165G>C } \\
\text { p.Gly389Arg }\end{array}$ & $\begin{array}{l}\beta 1-\mathrm{AR} \\
\text { c.145A }>\mathrm{G} \\
\text { p.Ser49Gly }\end{array}$ & $\begin{array}{l}\text { GNAS } \\
\text { c. } 393 \mathrm{C}>\mathrm{T} \\
\text { p. }(\mathrm{Ile} 131=)\end{array}$ \\
\hline 1 & $\mathrm{~A} / \mathrm{A}$ & $\mathrm{C} / \mathrm{C}$ & $\mathrm{C} / \mathrm{C}$ & $\mathrm{A} / \mathrm{A}$ & $\mathrm{C} / \mathrm{C}$ \\
\hline 2 & $\mathrm{~A} / \mathrm{A}$ & $\mathrm{C} / \mathrm{C}$ & $\mathrm{C} / \mathrm{C}$ & $\mathrm{A} / \mathrm{A}$ & $\mathrm{T} / \mathrm{T}$ \\
\hline 3 & $\mathrm{~A} / \mathrm{A}$ & $\mathrm{C} / \mathrm{C}$ & $\mathrm{C} / \mathrm{C}$ & $\mathrm{A} / \mathrm{G}$ & $\mathrm{T} / \mathrm{T}$ \\
\hline 4 & $\mathrm{~A} / \mathrm{A}$ & $\mathrm{C} / \mathrm{C}$ & $\mathrm{G} / \mathrm{C}$ & $\mathrm{A} / \mathrm{A}$ & $\mathrm{T} / \mathrm{T}$ \\
\hline 5 & $\mathrm{~A} / \mathrm{A}$ & $\mathrm{C} / \mathrm{C}$ & $\mathrm{G} / \mathrm{C}$ & $\mathrm{A} / \mathrm{A}$ & $\mathrm{T} / \mathrm{T}$ \\
\hline 6 & $\mathrm{~A} / \mathrm{A}$ & $\mathrm{C} / \mathrm{C}$ & $\mathrm{G} / \mathrm{C}$ & $\mathrm{A} / \mathrm{G}$ & $\mathrm{C} / \mathrm{T}$ \\
\hline 7 & $\mathrm{~A} / \mathrm{G}$ & $\mathrm{C} / \mathrm{C}$ & $\mathrm{C} / \mathrm{C}$ & $\mathrm{A} / \mathrm{G}$ & $\mathrm{T} / \mathrm{T}$ \\
\hline 8 & $\mathrm{~A} / \mathrm{G}$ & $\mathrm{C} / \mathrm{C}$ & $\mathrm{G} / \mathrm{C}$ & $\mathrm{A} / \mathrm{G}$ & $\mathrm{T} / \mathrm{T}$ \\
\hline 9 & $\mathrm{~A} / \mathrm{G}$ & $\mathrm{C} / \mathrm{C}$ & $\mathrm{G} / \mathrm{G}$ & $\mathrm{A} / \mathrm{A}$ & $\mathrm{C} / \mathrm{T}$ \\
\hline 10 & $\mathrm{~A} / \mathrm{G}$ & $\mathrm{C} / \mathrm{G}$ & $\mathrm{C} / \mathrm{C}$ & $\mathrm{A} / \mathrm{A}$ & $\mathrm{C} / \mathrm{T}$ \\
\hline 11 & $\mathrm{~A} / \mathrm{G}$ & $\mathrm{C} / \mathrm{G}$ & $\mathrm{C} / \mathrm{C}$ & $\mathrm{A} / \mathrm{A}$ & $\mathrm{C} / \mathrm{T}$ \\
\hline 12 & $\mathrm{~A} / \mathrm{G}$ & $\mathrm{C} / \mathrm{G}$ & $\mathrm{C} / \mathrm{C}$ & $\mathrm{A} / \mathrm{A}$ & $\mathrm{C} / \mathrm{T}$ \\
\hline 13 & $\mathrm{~A} / \mathrm{G}$ & $\mathrm{C} / \mathrm{G}$ & $\mathrm{C} / \mathrm{C}$ & $\mathrm{A} / \mathrm{A}$ & $\mathrm{T} / \mathrm{T}$ \\
\hline 14 & $\mathrm{~A} / \mathrm{G}$ & $\mathrm{C} / \mathrm{G}$ & $\mathrm{C} / \mathrm{C}$ & $\mathrm{A} / \mathrm{G}$ & $\mathrm{C} / \mathrm{C}$ \\
\hline
\end{tabular}




\begin{tabular}{|c|c|c|c|c|c|}
\hline Patient ID & $\begin{array}{l}\beta 2-A R \quad 46 \mathrm{~A}>\mathrm{G} \\
\text { Gly16Arg }\end{array}$ & $\begin{array}{l}\beta 2-\mathrm{AR} 79 \mathrm{C}>\mathrm{G} \\
\text { Gln27Glu }\end{array}$ & $\begin{array}{l}\beta 1-\mathrm{AR} \\
\text { c.1165G >C } \\
\text { p.Gly389Arg }\end{array}$ & $\begin{array}{l}\beta 1-\mathrm{AR} \\
\text { c.145A }>\mathrm{G} \\
\text { p.Ser49Gly } \\
\end{array}$ & $\begin{array}{l}\text { GNAS } \\
\text { c.393C }>\text { T } \\
\text { p. }(\text { Ile131=) }\end{array}$ \\
\hline 15 & $\mathrm{~A} / \mathrm{G}$ & $\mathrm{C} / \mathrm{G}$ & $\mathrm{C} / \mathrm{C}$ & $\mathrm{A} / \mathrm{G}$ & $\mathrm{C} / \mathrm{T}$ \\
\hline 16 & $\mathrm{~A} / \mathrm{G}$ & $\mathrm{C} / \mathrm{G}$ & $\mathrm{C} / \mathrm{C}$ & $\mathrm{A} / \mathrm{G}$ & $\mathrm{T} / \mathrm{T}$ \\
\hline 17 & $\mathrm{~A} / \mathrm{G}$ & $\mathrm{C} / \mathrm{G}$ & $\mathrm{G} / \mathrm{C}$ & $\mathrm{A} / \mathrm{A}$ & $\mathrm{C} / \mathrm{C}$ \\
\hline 18 & $\mathrm{G} / \mathrm{G}$ & $\mathrm{C} / \mathrm{G}$ & $\mathrm{G} / \mathrm{C}$ & $\mathrm{A} / \mathrm{A}$ & $\mathrm{C} / \mathrm{T}$ \\
\hline 19 & $\mathrm{G} / \mathrm{G}$ & $\mathrm{G} / \mathrm{G}$ & $\mathrm{C} / \mathrm{C}$ & $\mathrm{A} / \mathrm{A}$ & $\mathrm{C} / \mathrm{C}$ \\
\hline 20 & $\mathrm{G} / \mathrm{G}$ & $\mathrm{G} / \mathrm{G}$ & $\mathrm{C} / \mathrm{C}$ & $\mathrm{A} / \mathrm{A}$ & $\mathrm{C} / \mathrm{T}$ \\
\hline 21 & $\mathrm{G} / \mathrm{G}$ & $\mathrm{G} / \mathrm{G}$ & $\mathrm{C} / \mathrm{C}$ & $\mathrm{A} / \mathrm{A}$ & $\mathrm{C} / \mathrm{T}$ \\
\hline 22 & $\mathrm{G} / \mathrm{G}$ & $\mathrm{G} / \mathrm{G}$ & $\mathrm{C} / \mathrm{C}$ & $\mathrm{A} / \mathrm{G}$ & $\mathrm{C} / \mathrm{C}$ \\
\hline 23 & $\mathrm{G} / \mathrm{G}$ & $\mathrm{G} / \mathrm{G}$ & $\mathrm{C} / \mathrm{C}$ & $\mathrm{A} / \mathrm{G}$ & $\mathrm{C} / \mathrm{T}$ \\
\hline 24 & $\mathrm{G} / \mathrm{G}$ & $\mathrm{G} / \mathrm{G}$ & $\mathrm{C} / \mathrm{C}$ & $\mathrm{A} / \mathrm{G}$ & $\mathrm{C} / \mathrm{T}$ \\
\hline 25 & $\mathrm{G} / \mathrm{G}$ & $\mathrm{G} / \mathrm{G}$ & $\mathrm{G} / \mathrm{C}$ & $\mathrm{A} / \mathrm{A}$ & $\mathrm{C} / \mathrm{T}$ \\
\hline 26 & $\mathrm{G} / \mathrm{G}$ & $\mathrm{G} / \mathrm{G}$ & $\mathrm{G} / \mathrm{C}$ & $\mathrm{A} / \mathrm{A}$ & $\mathrm{C} / \mathrm{T}$ \\
\hline $\begin{array}{l}\text { Allele } \\
\text { incidence in } \\
\text { the study } \\
\text { population }\end{array}$ & $\mathrm{G}-55.8 \%$ & $\mathrm{C}-51.9 \%$ & $\mathrm{C}-80.8 \%$ & $\mathrm{~A}-80.8 \%$ & $\mathrm{~T}-55.8 \%$ \\
\hline $\begin{array}{l}\text { Allele } \\
\text { incidence in } \\
\text { the Estonian } \\
\text { population }{ }^{19}\end{array}$ & $\mathrm{G}-63 \%$ & $\mathrm{C}-58 \%$ & $\mathrm{C}-76 \%$ & $\mathrm{~A}-84.5 \%$ & $\mathrm{~T}-44.5 \%$ \\
\hline
\end{tabular}

AR-adrenoceptor.

Table 2. Results of model fitting.

HR GA + AUC + AUC: B1AR Arg389Gly (G/G or G/C)

\begin{tabular}{ll}
\hline & Value \\
Intercept & 191.6 \\
GA & -1.5 \\
AUC & 14.3 \\
AUC: B1AR Arg389Gly (G/G or G/C vs C/C) & 38.3 \\
SD of random intercept & 15.2 \\
SD of residual error & 12.7 \\
Autocorrelation parameter & 0.94 \\
LVO ANATGC:GA34 + SNAPPE-II + AUC + AUC: GNAS c.393C > T (T/T or C/T) & LVO ANATGC:GA34 + SNA \\
& Value \\
Intercept & 125.3 \\
SNAPPE-II & 1.3 \\
AUC & -4.5 \\
ANATGC:GA34 & -37.6 \\
AUC: GNAS c.393C>T (T/T or C/T vs C/C) & 24.5 \\
SD of random intercept & 30.2 \\
RVO of residual error & 27.1 \\
& RNAPPE-II + GA + AUC + AUC: GNAS c.393C > T (T/T or C/T) SNAPPE-II + GA + A \\
SNAercept) & Value
\end{tabular}


GA

AUC

AUC: GNAS c.393C $>\mathrm{T}(\mathrm{T} / \mathrm{T}$ or $\mathrm{C} / \mathrm{T}$ vs $\mathrm{C} / \mathrm{C})$

HR - heart rate; GA - gestational age; AUC - area under the time-plasma concentration curve; SD standard deviation; LVO - left ventricular output; SNAPPE-II - Score for Neonatal Acute Physiology Perinatal Extension; ANATGC:GA34 - antenatal glucocorticoid administration if born before 34 weeks of gestation; RVO - right ventricular output.

\section{FIGURE LEGENDS}

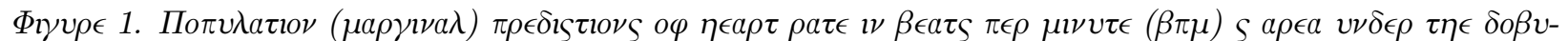

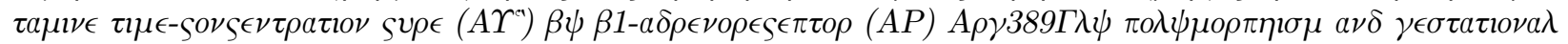

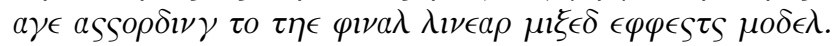

Figure 2. Population predictions of left ventricular output vs area under the dobutamine time-concentration curve $(A U C)$ by GNAS c.393C>T polymorphism and antenatal glucocorticoid administration and SNAPPEII score (1st Quantile: 8.50 3rd Quantile:25.75) according to the final linear mixed effects model.

Figure 3. Population predictions of right ventricular output vs area under the dobutamine time-concentration curve (AUC) by GNAS c.393C>T polymorphism, GA and SNAPPE-II score (1st Quantile: 8.50 3rd Quantile:25.75) according to the final linear mixed effects model.

\section{AUTHORS' CONTRIBUTIONS}

MH conceived the study, participated in its design, collected data, participated in data analysis, and drafted the manuscript. HS conducted data analysis and revised the manuscript. TK and ÜM organised and conducted genetic material analysis, participated in data analysis, and revised the manuscript. M-LI conceived the study, collected the data, and revised the manuscript. KK supported the work with LC-MS quantification of dobutamine. TM conceived the study, participated in its design, collected data, and drafted the manuscript. All authors read and approved the final manuscript.

The data that support the findings of this study are available from the corresponding author upon reasonable request. 

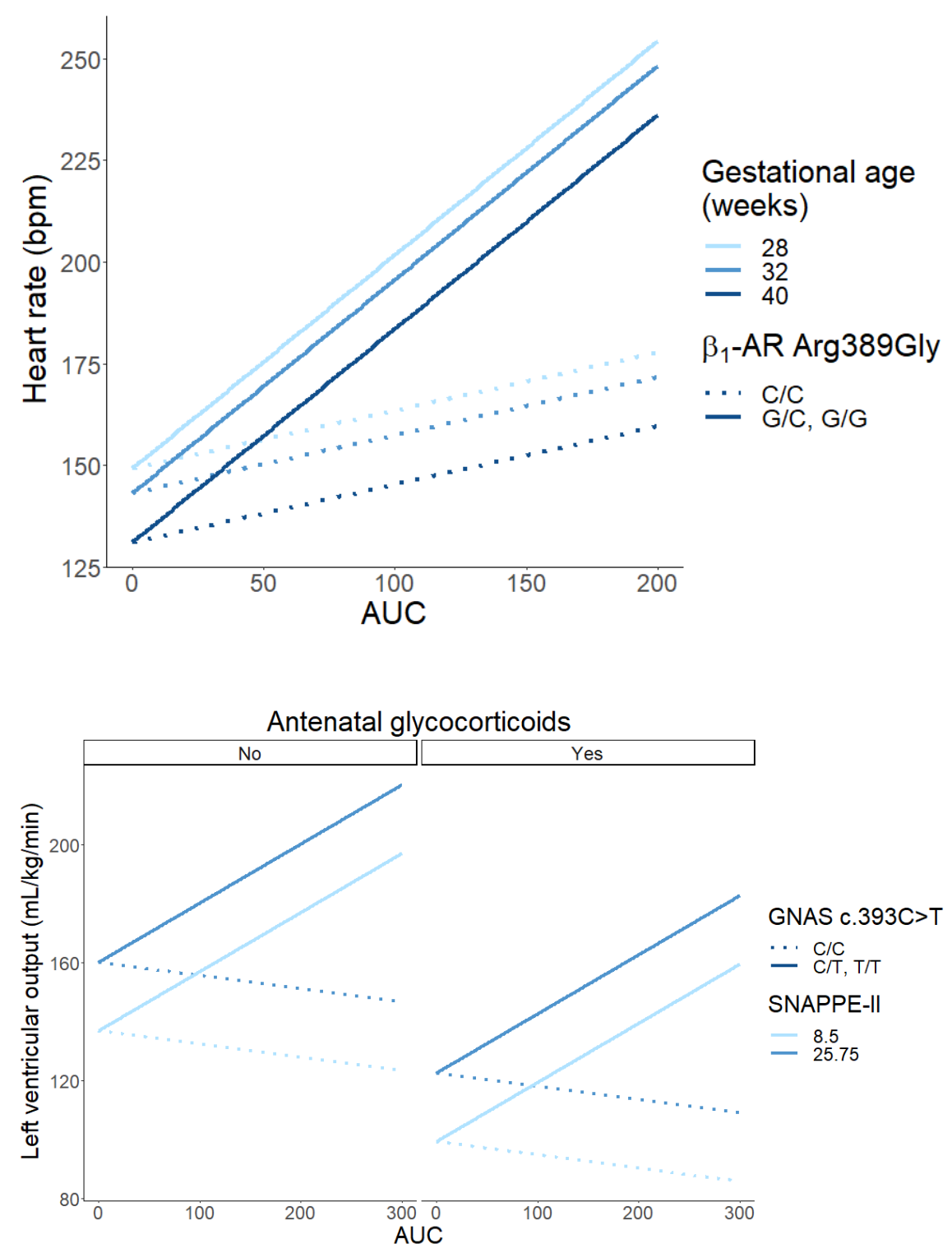


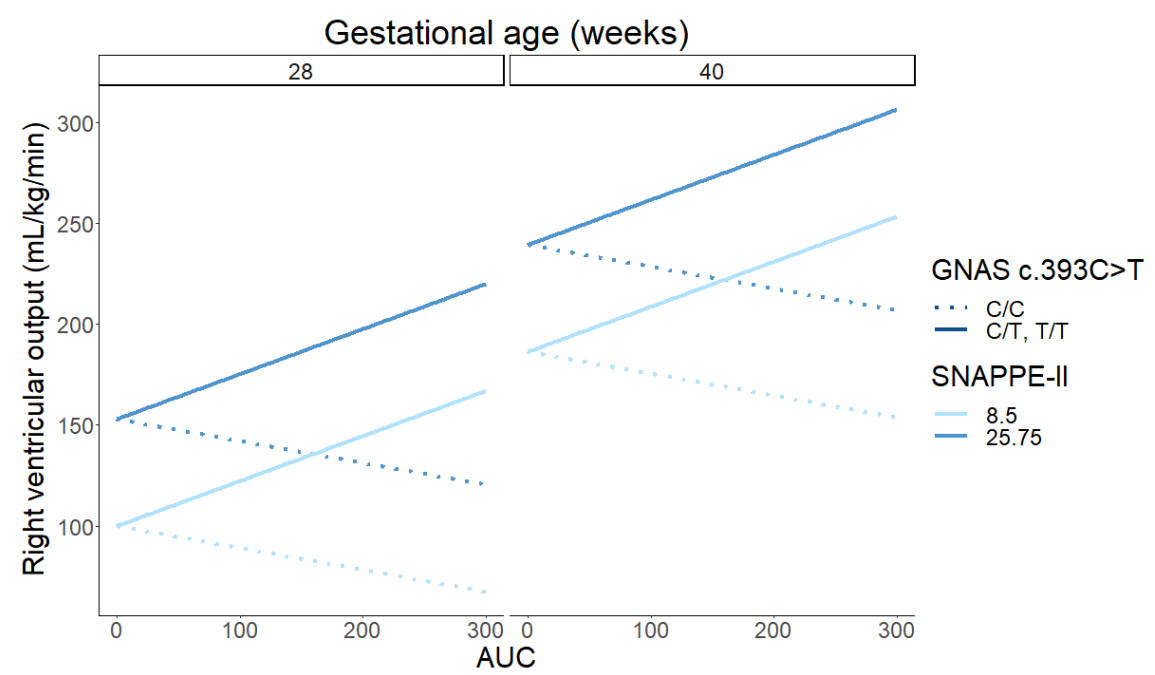

